\title{
Race, history, irresolution: Reflections on City of Tshwane Metropolitan Municipality $\checkmark$ Afriforum and the limits of "post"-apartheid constitutionalism
}

Joel M Modiri

$L L B$ PhD (Pret)

Senior Lecturer, Department of Jurisprudence, University of Pretoria

\begin{abstract}
SUMMARY
This article reflects on the limits of "post"-apartheid constitutionalism through an extended theoretical discussion and close reading of the Constitutional Court decision in City of Tshwane Metropolitan Municipality $v$ Afriforum and Another 2016 (6) SA 279 (CC). It focuses in particular on how South Africa's history of colonial conquest, white supremacy and racism and the nation's failure to reckon with that history - introduced a "constitutional irresolution" in the case. Developed by Emilios Christodoulidis as a critique of constitutional optimism in all its forms, "constitutional irresolution" describes what happens when constitutionalism, because of its institutional and rigid character, is unable to address political or legal contestations which challenge its own terms and norms. In this article, this irresolution is then related to the work of Mogobe Ramose and specifically his critique of how the negotiated settlement and transition of the 1990s followed a path of democratisation, which not only negated the exigency of decolonisation and historical justice but also resulted in the "constitutionalisation of the injustice arising from the unjust war of colonisation". Since City of Tshwane raised questions concerning race, belonging and the still colonial character of South African spaces, mind-sets and power relations, it illustrates the persistence of the colonial-apartheid past into the constitutional present. Among other things, I take this blurring of the divide between the past and the present to be an exposure of the limits, or irresolution, of "post"-apartheid constitutionalism and "post"-apartheid jurisprudence:
\end{abstract}

Race lives even as it is being constitutionally buried. In South Africa, race and racism constitute an impermanent conundrum, a conceptual incorrigibility in and for a society trying to imagine itself as non-racial. ${ }^{1}$

* This article draws on a chapter from my doctoral thesis entitled "The Jurisprudence of Steve Biko: A Study in Race, Law and Power in the 'Afterlife' of Colonial-apartheid" (PhD thesis 2018 UP), completed under the supervision of Professor Karin van Marle. My thanks to Karin for her support and critical insights. My gratitude is extended also to close colleagues Yvonne Jooste, Rantsho Moraka and comrades from the Azanian Philosophical Society for generative conversations relating to the research in this article.

1 Farred "Shooting the White Girls First: Race in Post-apartheid South Africa" in Globalization and Race: Transformations in the Cultural Production of Blackness (eds Clarke and Thomas) (2006) 66.

How to cite: Modiri 'Race, history, irresolution: Reflections on City of Tshwane Metropolitan Municipality $v$ Afriforum and the limits of "post"-apartheid constitutionalism' 2019 De Jure Law Journal 27-46 http://dx.doi.org/10.17159/2225-7160/2019/v52a2 
The postcolony, however hard it may try, sees the persistence of an infinite colonial sovereign imposition - that is, colonial sovereignty is rendered finite by adjusting, archiving, transforming the social and juridical order through a national liberation struggle, but to the extent that colonial juridical, economic, and social orders persist, the colonial usurpation has an infinite reach. ${ }^{2}$

\section{Introduction: shades of a problematic}

In this article, I provide an extended reading of the recent Constitutional Court case of City of Tshwane Metropolitan Municipality $v$ Afriforum. ${ }^{3}$ This is a case that stands out as particularly desperate for critical analysis given how dramatically the contradictions of South Africa's unresolved history of racial oppression, colonial conquest and white supremacy introduced an unsettling fracture not only between the judges of the Court but also in the foundations of the very idea of non-racial "post"apartheid constitutionalism. Although the case deals with a largely procedural and administrative dispute concerning the process of renaming streets in the city of Tshwane, it more significantly raises questions of memory, race, power, and how to respond to the almost four-centuries history of trauma, terror and tragedy that define colonialapartheid in South Africa.

I will thus read City of Tshwane as a case that highlights some of the fundamental complexities and limits - maybe even failures - of South Africa's present constitutional dispensation. I take as a starting point the many critical voices who have argued over many years that the choice in the early 1990s by the negotiators for a "new" South Africa to follow a path of post-conflict reconstruction based on liberal constitutionalism, rights discourse, amnesty and "reconciliation without justice" would be unsustainable and only reproduce unfreedom and inequality. ${ }^{4}$ For these critical voices, the constitutional transition in South Africa was characterized by statist and top-down discourses of forgiveness, unity and nation-building to the exclusion of justice, responsibility and reparations. The empty symbolism of the former discourses is evidenced

2 Motha "Archiving Colonial Sovereignty: From Ubuntu to a Jurisprudence of Sacrifice" 2009 SA Public Law 300.

3 City of Tshwane Metropolitan Municipality v Afriforum and Another 20166 SA 279 (CC).

4 See generally, Mamdani "Reconciliation without Justice" 1996 SA Review of Books 3-5; Mamdani "When Does Reconciliation Turn into a Denial of Justice?" in Sam Nolutshungu Memorial Lecture Series (1998) 1; Mutua "Hope and Despair for a New South Africa: The Limits of Rights Discourse" 1997 Harvard Human Rights J 68; Sibanda "Not Purpose Made! Transformative Constitutionalism, Post-independence Constitutionalism and the Struggle to Eradicate Poverty" 2012 Stellenbosch LR 482; Madlingozi "Social Justice in a Time of Neo-apartheid Constitutionalism: Critiquing the Anti-black Economy of Recognition, Incorporation and Distribution" 2017 Stellenbosch LR 123 - 147. See also Modiri "Conquest and Constitutionalism: First Thoughts on an Alternative Jurisprudence" 2018 SAJHR 300-325. 
by the way in which the terms of the negotiated settlement exonerated perpetrators and beneficiaries of colonial-apartheid of all historical and political responsibility and failed to comprehensively address questions of the restoration of land, economic redistribution and the reclamation of African culture and epistemologies. ${ }^{5}$ It follows from this that by failing to address the problem of historical and corrective justice, the new legal and political order would ultimately reveal irresolvable cracks and tensions that would overwhelm the coherence of the very idea of "post-apartheid South Africa”.

If, as the historical record shows, the very idea and name of "South Africa" is a construct and artefact of colonial sovereignty, having been imposed on this land by its two conquering powers in the Union of 1910 as part of a larger project of remaking the entire territory in the image of Europe, into what would be called "white South Africa", 6 then "South Africa" itself emblematises the dispossession, suffering, oppression and unsovereign existence of the indigenous conquered peoples of this part of the world. On this view, the project of a number of critical legal scholars in South Africa to develop a "post-apartheid jurisprudence" that, through mourning, transformation and critique, could repudiate the conservative legal culture of apartheid and its lack of an ethical politics, ${ }^{7}$ is analytically and historically misplaced since it was the longue durée history of colonial conquest and white supremacy and not the halfcentury juridical formation of apartheid that is the founding of South Africa's contractions. ${ }^{8}$ Whereas post-apartheid jurisprudence conceives of the present South Africa as an imperfect and complex formation of political community struggling to overcome its past, this note works from the prism of post-conquest jurisprudence, which in contrast treats the idea of South Africa as an unjust and unethical formation and also as a foundationally impossible site of community, subjectivity and relation.

5 Ramose "An African Perspective on Justice and Race"” 2001 Polylog http:// them. polylog.org/3/frm-en.htm "In Memoriam: Sovereignty and the 'New' South Africa" 2007 Griffith LR 318-319; "Reconciliation and Reconfiliation in South Africa" 2012 J of African Philosophy 33.

6 Fredrickson White Supremacy: A Comparative Study in American and South African History (1981) 179 - 198; Saul and Bond South Africa - The Present as History: From Mrs Ples to Mandela \& Marikana (2014) 36.

7 For some representative writings, see Van der Walt Law and Sacrifice: Towards a Post-apartheid Theory of Law (2005); Le Roux "The Aesthetic Turn in Post-Apartheid Constitutional Rights Discourse” 2006 TSAR 101-120; Cornell "Ubuntu, Pluralism and the Responsibility of Legal Academics to the New South Africa" 2009 Law \& Critique 43 - 58; Van Marle "Reflections on Post-apartheid Being and Becoming in the Aftermath of Amnesty" 2010 Constitutional Court Review 347 - 366. See also the writings collected in Van Marle and Le Roux (eds) Post-apartheid Fragments: Law, Politics and Critique (2007)

8 See Dladla Here is a Table: A Philosophical Essay on the History of Race in South Africa (2016) and Cavanagh "Settler colonialism in South Africa: land, labour and transformation 1880 - 2015" in Routledge Handbook of the History of Settler-colonialism (eds Cavanagh and Veracini) (2017) 291 - 308. 
This is a significant distinction since the primary jurisprudential contention in this case revolved around the relationship between the Constitution and South Africa's history of colonial racism and spatial injustice. The Court had to answer the question of whether the Constitution's professed vision of a non-racial, democratic and united society accommodates, protects and affirms both the historical memory and experience of the historically oppressed Black community as well as the political worldview and cultural history of the white minority population. Another way to put this is whether the Constitution can contain the fundamentally incommensurable and conflicting histories of both the conquered and the conqueror. But does settler-colonialism not have as its ultimate aim the elimination or disappearance of the native subject? ${ }^{9}$ Is it truly possible to reconcile the forms of life of Black people in South Africa, still reeling from an unliveable history of subjugation and of being made foreigners in the land of their birth, to those of white South Africa, descendants of European colonialists and immigrants whose existence and presence has its historical basis in domination and racism?

It is in the quite different formulations of the above problematic by the majority judgment (authored by the Chief Justice with the concurrence of all the black judges of the Court) and the minority judgment (authored by the only two white judges of the Court) that the "post"-apartheid Constitution - as historical text, civic language, political culture and social consciousness - appears fragile and malleable, unable to hold together the civic bonds of the nation, and incapable of reckoning with the past and the present. To my mind, the very event of this case attests to the "non-constitutive" character of the post-1994 South African Constitution - the fact that it did not reconstitute or bring about a truly new society and polity. This failure of the Constitution to constitute and represent a non-racial "we" that could share the space of the city of Tshwane is not unrelated to its overall historical inability to address the injustice of colonial conquest and its afterlives - structural racism, land dispossession, economic inequality, spatial segregation, violence, epistemicide and perennial social disharmony. As I will attempt to illustrate, the affective, political and historical lines of reasoning developed in the different judgments that compose this case reflect something of a structurally and symbolically overburdened project of constitutionalism, a constitutionalism that can no longer conceal its failures and silences.

This article will unfold as follows: In the section that follows (section 2), I engage with the notion of "constitutional irresolution", as put forward by Emilios Christodoulidis, through an interlocution with the work of Mogobe Ramose and other scholars. The aim will be to situate the reading of the City of Tshwane judgment(s) within the context of the critique of constitutional optimism and of the faulty terms of the negotiated settlement, which gave rise to the new constitutional

9 Wolfe "Settler colonialism and the elimination of the native" $2006 \mathrm{~J}$ of Genocide Research 387 - 409. 
dispensation. I shall thereafter (in section 3), draw on the foregoing discussion to examine the City of Tshwane judgment through a close reading of its rhetorical structure and the interpretive tensions between the majority judgment by Mogoeng $\mathrm{CJ}$, the minority judgment by Froneman and Cameron JJ as well as the separate concurring judgment by Jafta J. The constraints of space may not allow the full argument as sketched in the background above to come through so what is offered here is only shades of a much larger and longer critical project.

\section{The irresolute constitution}

In thinking through a critique of "the constitutional optimism that pervades our political rationality”, ${ }^{10}$ legal theorist Emilios Christodoulidis introduced the notion of "constitutional irresolution" as a way of drawing attention to that which dominant modes of legal-constitutional representation "both brings into presence and misses". ${ }^{11}$ Christodoulidis argues for emphasis to be placed on "bearing witness to what is missed". ${ }^{12}$ With this notion of constitutional irresolution, Christodoulidis opposes conceptions of constitutionalism which claim or attempt to contain politico-historical tensions in the polity and play host to plurality. He is critical of a variety of constitutional optimisms - from those which insist on the need for consensus, unity and shared normative interpretation to those more ambitious attempts to include organised and disorganised elements of civil society into the structure of constitutional construction and negotiation. ${ }^{13}$ For Christodoulidis, all forms of constitutional optimism ignore the fundamental "institutional constraints" that come with constitutionalism, by which he means that the coupling of law and constitutionalism with the political, plurality, agonism and contestation is a structural impossibility due to law's systematic inclination to fix and reduce social complexities. ${ }^{14}$

Christodoulidis' arguments here serve as a particularly apposite response and problematisation of attempts also in South Africa to figure the Constitution and constitutionalism variously as (1) a vehicle for nation-building and reconciliation; ${ }^{15}$ (2) a normative framework for historically-responsive social transformation; ${ }^{16}$ (3) a fundamental

10 Christodoulidis "Constitutional Irresolution: Law and the Framing of Civil Society" 2003 European LJ 401.

11 Christodoulidis 2003 European LJ 403.

12 Christodoulidis 2003 European LJ 403.

13 Christodoulidis 2003 European LJ 404.

14 See generally Christodoulidis Law and Reflexive Politics (1998).

15 See e.g. Langa "Transformative Constitutionalism" 2006 Stellenbosch LR 351 - 360; Mbembe "Apartheid Futures and the Limits of Racial Reconciliation" (2015) Unpublished paper available at http://wiser.wits.ac.za/system /files/documents/Mbembe \% 20-\% 202015\% 20-\% 20Public \% 20Positions \% 20-\% 20Apartheid \% 20Futures.pdf.

16 See e.g. Klare "Legal Culture and Transformative Constitutionalism" 1998 SAJHR 146; Albertyn and Goldblatt "Facing the Challenge of Transformation: Difficulties in the Development of an Indigenous 
rupture with the legal and political values of the "old" order of colonialapartheid, ${ }^{17}$ and as (4) a founding instrument that binds South Africans together into a "people" with a shared national identity. ${ }^{18}$ At once deified and sentimentalized, the South African Constitution is optimistically cast not only as the supreme law of the nation but also as the governing blueprint and grammar of South African social, legal and political life, a supreme rationality that defines the parameters of all speech and action. But as Christoudilidis illustrates, such attempts by constitutional optimists to develop an all-inclusive and democratic constitutionalism are terminally non-performative and incapable of resisting the "topdown logic" of constitutionalism as well as the "the fixity of constitutional determinations". 19

Christodoulidis critically examines two dominant strands of constitutional optimism - which he names "constitutional pluralism" and "constitutional agonism" respectively -and concludes that both theoretical approaches to constitutionalism "invite constitutional orders to exhibit an impossible reflexivity" ${ }^{20}$ Christodoulidis elaborates on this further through a critical legal rendition of Systems theory. He argues that constitutional optimists fail to realize the inherent "institutional limits of constitutional politics": precisely the ways in which (constitutional) law fixes contingency, draws lines and stabilizes meaning through institutionalization and thereby forecloses contestation and excludes certain voices and perspectives from legal discourse:

Institutionalisation imports a mundane sort of violence to this effect: not everything can be contested, not everything finds its way into legal categories. The ambit of all that could be contested is delimited by institutional categories that determine there who, the how and the when of constitutional politics. ${ }^{21}$

This regulatory and stabilizing institutional function of law also has the effect of providing norms and procedures that allow all conflicts to be treated, indeed ordered, as resolvable. ${ }^{22}$ Constitutional politics, as a politics that grounds an order, is not open to conflicts that cannot be resolved. It is not open to antagonisms that call either dominant power

Jurisprudence of Equality" 1998 SAJHR 248-276; De Vos “The Past is Unpredictable: Race, Redress and Remembrance in the South African Constitution" 2012 SALJ 73 - 103.

17 See e.g. Van Der Walt "Normative Pluralism and Anarchy: Reflections on the 2007 term" 2008 Constitutional Court Review 77 - 124; Cornell Law and Revolution in South Africa: Ubuntu, Dignity and the Struggle for Constitutional Transformation (2014); Davis "Transformation: The Constitutional Promise and Reality” 2010 SAJHR 85 - 101.

18 See e.g. Ndebele "Our Dream is Turning Sour” (2011-09-25) The Sunday Times http://www.timeslive.co.za/opinion/commentary/2011/09/25/part-1 our-dream-is-turning-sour; Sachs We, the People: Insights of an Activist Judge (2017).

19 Christodoulidis 2003 European LJ 405.

20 Christodoulidis 2003 European LJ 411; see discussion on pages 403 - 411 .

21 Christodoulidis 2003 European LJ 413.

22 Christodoulidis 2003 European LJ 414. 
arrangements of a society or a constitution's own terms and foundations into question. In this respect, constitutional law also imposes a particular, official and hegemonic historical and national narrative, a way of understanding the social, the political and the historical that accords with its assumptive legitimacy and authority. As Christodoulidis explains, legal and constitutional argument and reasoning "is always-already disciplined by the contextual conditions, therefore no longer reflexive about them."23 A constitution's own capacity for inclusivity, democratic openness and political deliberation is undercut by its aversion to "structure-defying challenges":

The asking price for a politics of law, for a constitutional politics, is that the legal structure in the situations that it structures is not itself put to the test. ${ }^{24}$

Christodoulidis further highlights two paradoxes or "irresolutions" inherent to constitutionalism, namely its drive for closure which undercuts its ability to host the "irreducible disagreement" at the heart of politics, ${ }^{25}$ as well as its inability to simultaneously effect and represent, while also enabling the renegotiation of, a "we", a demos or a constituency. ${ }^{26}$ It occurs here that there is a striking parallel between Christodoulidis' critique of constitutionalism and that of Mogobe Ramose.

In his critique of the paradigm of constitutional supremacy in South Africa, Ramose points out an essential distinction between constitutionalism (-ism) and the "-ness aspect" of Ubuntu philosophy. ${ }^{27}$ For Ramose, African philosophy works from the premise that "motion is the principle of being". Consequently, the African ontology of law proceeds as a -ness and not an -ism - the former evoking dynamism and motion; the latter denoting fixity and immutability. ${ }^{28}$ The implication of this philosophical and linguistic distinction is that it is inherent to constitutional-ism to construe the Constitution as fixed, transcendent and immutable and therefore not responsive to contingency, radical openness and political contestation. Since everything in human life including law, politics and society - is in incessant and perpetual flow, it is necessary, argues Ramose, "to remain open to change and not to block it by imposing an arbitrary finality ...". 29 Yet it is the drive to finality that is the source of the "irresolution" Christodoulidis identifies as inherent to constitutional-ism.

In the reading of City of Tshwane judgment below, I will attempt to trace how the histories of race and conquest in South Africa introduced a similar "irresolution" that thwarts the closure, finality and stability to

23 Christodoulidis 2003 European LJ 415.

24 Christodoulidis 2003 European LJ 416.

25 Christodoulidis 2003 European LJ 417.

26 Christodoulidis 2003 European LJ 421

27 Ramose "Ubuntu: Affirming a Right and Seeking Remedies in South Africa" in Ubuntu: Curating the Archive (eds Praeg and Magadla) (2014) 133.

28 Ramose Ubuntu: Curating the Archive 133.

29 Ramose Ubuntu: Curating the Archive 133. 
which constitutionalism aspires. In City of Tshwane, the Court was confronted with a matter that troubled the terms and foundations of the Constitution and yet was strained to resolve it within the parameters of that text. In other words, the Court was haunted by a history that we have failed to reckon with. The constitutional vision of a multicultural nation, a non-racial, united and free society came up against "the insistent persistence of the colonial", 30 the resilience of white social and economic power and the intransigence of colonial spatialities and mindsets. On display in the case was a nominally "post-apartheid" society that still adheres to a colonial-apartheid spatial imaginary; a white political community that still refuses democratic Black majority rule in a legal system that enables such refusal; and the shattering of Human relationality that results in an historical, experiential and political incommensurability and lack of mutuality between the Black and white inhabitants of Tshwane and more broadly, South Africa. The paradox is that the present Constitution claims to have dismantled the old colonialapartheid order and instituted a new one, based on transformative and democratic values, but is faced in this case with the living falsity of this claim. This case is thus a remarkable instance of "constitutional irresolution" since it poses a challenge that defies or undermines the very structure and logic of the Constitution.

A central theme throughout Ramose's oeuvre on South African jurisprudence is that the irresolution described above is closely tied to the faulty foundations of the negotiated settlement and the process of transition from colonial-apartheid to constitutional democracy undertaken in South Africa in the early 1990s. Ramose analyses the constitutional negotiations for a "new" South Africa in terms of the two contending paradigms that were at play during that time, namely the democratisation paradigm versus the decolonisation paradigm. ${ }^{31}$

The democratisation paradigm assumes that the major problem of apartheid was one of racial disenfranchisement and denial of basic civil rights to Blacks. In this paradigm, a key fundament of achieving a new democratic dispensation would be the inclusion of Blacks into the existing legal, political and economic regime and the promulgation of democracy and non-racialism. ${ }^{32}$ Because of the focus on apartheid - a fleeting event (from 1948 - 1994) in the now almost four centuries of white supremacy's reign in South Africa - the democratisation paradigm entirely lost sight of the question of land which is a problem that predates the formal institutionalisation of apartheid. ${ }^{33}$ Already in 1993, Ramose,

30 Tuitt "Used Up and Misused: The Nation State, the European Union and the Insistent Presence of the Colonial" 2012 Columbia Journal of Race and Law $490-498$.

31 Ramose "I Conquer, Therefore I am the Sovereign" in The African Philosophy Reader (eds Coetzee and Roux) (2003) 570.

32 Ramose The African Philosophy Reader 570.

33 Ramose The African Philosophy Reader 570. See also Ramose "Historic Titles in Law" in The African Philosophy Reader (eds Coetzee and Roux) (2003) $541-543$. 
together with Lesiba Teffo, had hypothesised that a core ideological constituent of the democratisation paradigm was "the illusion of freedom" through which Blacks would be inserted into a new order of racial domination "not by coercion as in the past, but by consent."34 Democratisation thus results in the moral and political maintenance of the racist foundations of South Africa and the continuation of racially oppressive conditions in the guise of a liberal democratic state where the exigency of restoring parity and equality would remain forever deferred. As such, Ramose concludes that the democratisation paradigm is perfectly "consistent with the conqueror's claims" to land, property, power and wealth unjustly acquired through conquest and violence. 35 The democratisation paradigm is thus fundamentally preservative of the colonial-apartheid social (and spatial) fabric. It maintains the accumulated inequalities through the new legal order and envisages the equal participation of all members of a society in a still unjust and unethical polity.

On the extreme opposite, the decolonisation paradigm involves precisely the "dissolution of the conqueror's South Africa" through the restoration of title to territory and sovereignty over it to its indigenous people. ${ }^{36}$ Decolonisation seeks to effect a fundamental alteration in the power relations, and the epistemological and ontological framework, of South African society. It aspires not merely to the enfranchisement and inclusion of the oppressed into the existing framework but a reorganisation and repair of the polity. It abolishes the polity as imagined and instantiated by the European colonialist and dissolves the very categories of coloniser and colonised, settler and native, and Black and white as material social realities and not merely nominal juridical labels. Decolonisation, then, marks both the end of the white settler State and the opening to a post-conquest world. The decolonisation paradigm represents a deeper and more expansive and extensive conception of justice that responds to the experience of the indigenous conquered peoples of South Africa. Yet, it was of course the rights-based democratisation paradigm and its illusory freedom that carried the day in the constitution-making and nation-building process of the early 1990s, resulting in what Ramose calls "the constitutionalisation of injustice" 37 or what he elsewhere describes as the "forced transmutation of injustice into justice". 38

The ultimate choice for the democratisation paradigm is also epistemological for Ramose, as it is linked to the adoption of a Western legal paradigm and discourse that is neither autochthonous nor

34 Teffo and Ramose "Steve Biko and the Interpreters of Black Consciousness: a response to Lotter" 1993 Acta Academica 11.

35 Ramose The African Philosophy Reader 570.

36 Ramose The African Philosophy Reader 570.

37 Ramose The African Philosophy Reader 570,

38 Ramose The African Philosophy Reader 560. 
democratically legitimate since the majority of the population had no real say in its adoption. ${ }^{39}$ This reinforces the epistemicide that was central to the original injustice of colonialism and apartheid. By annihilating and dismissing the experiences and knowledges of the indigenous people and replacing it with the coloniser's own unilaterally defined meanings of truth, knowledge and experience, the epistemological structure of the "new" constitutional dispensation tacitly legitimises the colonial assumption that African people by virtue of their lack of civilisation and rationality are incapable of producing knowledge with which to govern themselves and to make sense of the(ir) world. ${ }^{40}$

Accordingly, the "transformation" brought about by the Constitution could be described as profoundly "non-constitutive" in the sense that the formal abolishment of apartheid was followed only by a general reform of constitutional law and the processes, systems and rules of South African law but not by a fundamental reorganisation of the way in which South Africa is economically, socially and politically constituted and organised. Put differently, the transition to constitutional democracy in South Africa was non-constitutive in the sense that it did not bring about radically new values and social relations. Hence Ramose's assertion that the Constitution represents a "second conquest" not only in its legitimation of the results of colonial land dispossession and exploitation, but also in its subordination of indigenous law and African jurisprudence. ${ }^{41}$ He thus reads the Constitution as a form of reiterative violence in the sense that the fundamental injustice of the "old" order was preserved in the making of the putatively "new" order. In his words:

[T] he injustice of conquest ungoverned by law, morality and humanity was constitutionalised. This constitutionalisation of injustice places the final constitution on a precarious footing because of its failure to respond to the exigencies of natural and fundamental justice [that is] due to the indigenous conquered peoples. ${ }^{42}$

Ramose's prediction that "post"-apartheid constitutionalism will always stand on a "precarious footing" due to its failure to reckon with the history of conquest suggests that the foundations of the South African constitutional order will continue to be unstable, overwrought, and lacking the grounds for universal legitimacy. ${ }^{43}$ As he explains:

[L]egal justice is not always the same as natural and moral justice. The option for democracy and non-racialism cannot replace the exigencies of justice in the form of restoration and restitution. Nor can it erase these from the

39 Ramose 2007 Griffith LR 320. See also Ramose "The King as Memory and Symbol of African Customary Law" in The Shade of New Leaves. Governance in Traditional Authority: A Southern African Perspective (ed Hinz) (2006) $353-355$.

40 See Ramose African Philosophy Through uBuntu (1999) 5-28.

41 Ramose 2007 Griffith LR 310 - 329.

42 Ramose The African Philosophy Reader 572. My emphasis.

43 Ramose "The Philosophy of the Anglo-Boer War" in A Century is a Short Time: New Perspectives on the Anglo-Boer War (eds Snyman et al) (2005) 2223. 
memory of historical justice. For these reasons a post-conquest South Africa is yet to be born ...44

This is why the Constitution and its attempts at closure and consensus will always be haunted, rendered irresolute, by the demand for true and concrete justice.

\section{City of Tshwane: history beside itself}

\section{Factual background}

City of Tshwane, ${ }^{45}$ concerns the renaming of 25 streets in the city of Tshwane/Pretoria. ${ }^{46}$ The Council had earlier passed a resolution to implement changes to the street names in the inner city of Tshwane/ Pretoria to reflect the "shared heritage" of all South Africans. ${ }^{47}$ After requesting that the City remove the new street names, Afriforum instituted an application for a restraining order preventing the City from removing the old street names pending a review of the Council's decision. Some months later however, after Afriforum had failed to launch a review application, the Mayor announced that the old street names would be permanently removed. Afriforum then applied for an urgent interdict ordering the City to retain the old street names underneath the new street names and to restore those that had already been removed pending the finalization of the review application which was still pending in the High Court. In its review challenge, Afriforum argued essentially that the Council's decision to rename the streets was invalid on the grounds that the City had not facilitated adequate public participation in the renaming process and moreover that the decision violated the cultural and environmental rights of the white Afrikaner community.

The City on the other hand responded that it was exercising its exclusive constitutional powers to govern the City in line with its vision for Tshwane/Pretoria to become a "new African Capital City, reflective of a common heritage, identity and destiny". The City also embarked on the renaming process in an effort to celebrate and honour the heroes and heroines of the "formerly" oppressed Black community. Among the new street names were iconic activists and intellectuals of the anti-apartheid struggle: Steve Biko, Robert Sobukwe, Jeff Masemola, Charlotte Maxeke, Lillian Ngoyi, Nelson Mandela and Walter Sisulu. Also included were three white anti-apartheid activists - two of whom were prominent Afrikaner theologians: Johan Heyns, Nico Smith and Helen Joseph. The High Court ultimately ruled in favour of Afriforum and granted the order restraining the City from removing any of the old street names and

44 Ramose A Century is a Short Time: New Perspectives on the Anglo-Boer War 22- 23.

45 City of Tshwane Metropolitan Municipality v Afriforum supra, para 1.

46 City of Tshwane $v$ Afriforum supra, para 1.

47 City of Tshwane $v$ Afriforum supra, para 1. 
directing them to restore those that had been removed. The City's appeal of the High Court's decision serves as the basis of the case in the Constitutional Court which as we will see addressed itself to the substantive questions regarding constitutional rights, history, race and culture rather than the more formal questions concerning the principle of legality and the procedure relating to interdicts.

\section{Majority judgment}

As has become standard in racially and historically contentious cases, Mogoeng $\mathrm{CJ}$ begins the judgment with a narration of the history of South Africa that led to the dispute over street names. Although he opens with a rehearsal of the peculiar doxa of South Africa as a country now "liberated" from a system of institutionalised racial oppression, he does tie this to a recognition that "colonialism or apartheid is a system so stubborn that its harmful effects continue to plague us and retard our progress as a nation ...". ${ }^{48}$ In the context of the case at hand, Mogoeng $\mathrm{CJ}$ notes that this continuing plague of the past is evidenced by the fact that almost all major cities, towns and street names in South Africa still bear references to figures of the colonial and apartheid "past". He thus takes issue with the fact that when attempts are made to progressively change these names, they are repeatedly faced with legal challenges. ${ }^{49}$

For Mogoeng $\mathrm{CJ}$, the "all-inclusive constitutional project" that was formally embarked upon in the early 1990s in pursuit of national unity and reconciliation requires that the injustices of the past "not be pampered ...".50 He adds that "the immeasurable damage racism or cultural monopoly has caused requires strict measures be taken to undo it." 51 In markedly combative language, the Chief Justice argues that maintaining symbols that resonate with our oppressive "past" and which venerate the heroes and heroines of a single racial group perpetuates the historical denigration of African people and indeed constitutes racial domination. The fact that South Africa "still looks very much like Europe away from Europe" 52 is, in his view, antithetical to the "constitutional reality" and "constitutional vision in South Africa". 53 As he further states:

A very insignificant number of names of our cities, towns and streets gives recognition to the indigenous people of this country and other black people. Very little recognition or honour is given to their heritage, history, heroes and heroines in their own motherland. This does not reflect but rather belies a commitment by all to the spirit of genuine unity, transformation and reconciliation. ${ }^{54}$

48 City of Tshwane $v$ Afriforum supra, para 2.

49 City of Tshwane $v$ Afriforum supra, para 4.

50 City of Tshwane $v$ Afriforum supra, para 6

51 City of Tshwane $v$ Afriforum supra, para 6.

52 City of Tshwane $v$ Afriforum supra, para 12.

53 City of Tshwane $v$ Afriforum supra, para 7, 9, 11 and 14.

54 City of Tshwane $v$ Afriforum supra, para 12. 
The work of the Constitution for Mogoeng $\mathrm{CJ}$ is to contain political community through its promulgation of a singular rationality and mindset and sameness of vision - what he calls "shared values" ${ }^{55}$ In his own words:

All peace and reconciliation-loving South Africans whose world-view is inspired by our constitutional vision must embrace the African philosophy of "ubuntu". "Motho ke motho ka batho ba bangwe" or "umuntu ngumuntu ngabantu" (literally translated it means that a person is a person because of others). The African world-outlook that one only becomes complete when others are appreciated, accommodated and respected, must also enjoy prominence in our approach and attitudes to all matters of importance in this country, including name-changing. White South Africans must enjoy a sense of belonging. But unlike before, that cannot and should never again be allowed to override all other people's interests. South Africa no longer "belongs" to white people only. It belongs to all of us who live in it, united in our diversity. Any indirect or even inadvertent display of an attitude of racial intolerance, racial marginalisation and insensitivity, by white or black people, must be resoundingly rejected by all South Africans in line with the Preamble and our values, if our constitutional aspirations are to be realized. ${ }^{56}$

Within the judge's non-racial constitutionalism, the nation-building tropes of "inclusivity", "reconciliation", "unity", "transformation" and "social cohesion" stand central. He is at pains to invoke and affirm a "oneness", however elusive, between South African citizens and so argues that the Constitution militates against the respondent's (Afriforum) "never-ending determination to oppose change to city, town and street names". ${ }^{57}$ Indeed, according to Mogoeng CJ, the Constitution places on all of "us" a "duty to transform". 58 It is inarguable that Mogoeng CJ is clearly unsympathetic to Afriforum's application. For him, as a matter of both law and political morality, the preservation of colonial-apartheid era street names and the promotion of sectarian white interests through legal technicalities is fundamentally irreconcilable with the constitutional project. ${ }^{59}$ Afriforum's claim that the old street names are a core part of their right to culture and that their removal threatens their very sense of belonging as South Africans was thus firmly rejected by the majority. ${ }^{60}$

Mogoeng CJ's decision with the support of all the Black judges of the Constitutional Court comes out quite openly as a refusal to entertain discourses of white victimhood and reverse racism upon which the respondents' claim was based. This importantly undermines the oftnoted phenomenon of well-resourced and litigious individuals and organisations representing the vested interests of beneficiaries of historical injustice using their massive economic power to convert courts

55 City of Tshwane $v$ Afriforum supra, para 9.

56 City of Tshwane $v$ Afriforum supra, para 11

57 City of Tshwane $v$ Afriforum supra, para 14.

58 City of Tshwane $v$ Afriforum supra, para 14.

59 City of Tshwane $v$ Afriforum supra, paras 18-19.

60 City of Tshwane $v$ Afriforum supra, paras 26-27. 
into instruments for opposing democratic rule through procedural technicalities. In that sense, Mogoeng $\mathrm{CJ}$ is speaking back to the more optimistic, conciliatory tone of the earlier Constitutional Court jurisprudence on matters of race, highlighting that the promise of a reconciled, and united society has not materialised. The South Africa that is the scene of the City of Tshwane case appears still profoundly unsettled by race and it is evident that through his unambiguous language, the Chief Justice is also responding to the climate of increased raceconsciousness in public discourse and vocal doubts concerning the transformative capacity of the Constitution. He may also have been paying attention to protests in South African universities calling for decolonisation of South African institutions and spaces.

However, because he must rely on the constitutional text for both rhetorical substance and legal justification, his judgment also works within a set of unresolved tensions or paradoxes which, if pressed, can reveal contradictions and instabilities within the constitutional archive itself. These paradoxes include: (1) the memory of a putatively overthrown colonial order which nevertheless persists presently in the spatial organization and symbolic order of South Africa; (2) the articulation of a "strong" politics of race mediated through a moderate and liberal constitution; (3) a critique of the colonial "past" that relies on a largely Western legal paradigm; (4) the (Africanist) claim that South Africa is the "motherland" of indigenous African peoples but also (the Charterist assertion) that it belongs to all who live in it; and (5) a nonracial constitutionalism tied to the relentless naming of racial groups as "Black" and "white".

The irresolution that results from these paradoxes suggests among other things that the Constitution by design compels the co-existence rather than resolution of historically opposed forces. This is problematic given that there is certainly an irreconcilability between the histories and cultures of the conqueror and of the conquered - since the former exists through the subjugation and annihilation of the latter or put differently, since the two can only exist in Manichean opposition. The point may be precisely for white South Africans to disavow (without forgetting) their heritage in the world of European conquest and white supremacy in order to be reconciled to this place and to its people. In the philo-praxis of Black Consciousness intellectual, Steve Biko, to overcome the human apartness that settler-colonialism instantiates between the white settlers and the native African population in particular, the subject-positions (including cultural identities) that the settler population inherited from colonial-apartheid must be fundamentally transformed, not accommodated. Repeatedly utilising the metaphor of the "table", Biko articulates a conception of decolonisation that is not a mere inversion in power relations or a simple "turning of tables" ${ }^{61}$ It also does not amount

61 Biko I Write What I Like (1978) 108. 
to acceding to white power and seeking a "place at the white man's table". ${ }^{62}$ Instead he writes:

We knew he had no right to be there; we wanted to remove him from our table, strip the table of all trappings put on it by him, decorate it in true African style, settle down and then ask him to join us on our own terms if he liked. ${ }^{63}$

Thus both the extreme opposites of vengeful expulsion of the settler population and acquiescent submission to the extant colonial order are ruled out in Biko's liberatory vision. Biko instead envisions the reclamation of sovereignty by the indigenous conquered peoples and the reconstitution of a plural society on African terms. White South Africans, having relinquished title to territory, disavowed European supremacy and renounced white privilege, can only at this point be incorporated into a decolonised, non-racial Azania on condition that they accept democratic African political rule. As we noted in the discussion of Ramose above, it is precisely this decolonisation vision of post-conflict reconstruction that was negated by the democratisation logic of the present constitutional order.

\section{Minority judgment}

The tension in City of Tshwane would nevertheless deepen in the dissenting judgment written by the only remaining white judges of the Court - justices Johan Froneman and Edwin Cameron. In a way, the divergence in opinion between Mogoeng $\mathrm{CJ}$ and the Black judges who support his majority decision and Froneman and Cameron $\mathrm{JJ}$ is a metaphor for the persistence of race as a critical fault-line in society and a reflection of the still "unsettled" character of South Africa. The central basis of Froneman and Cameron JJ's dissent concerns their interpretation that the majority judgment is effectively suggesting that "reliance by white South Africans, particularly white Afrikaner people, on a cultural tradition founded in history finds no recognition in the Constitution because that history is inevitably rooted in oppression". ${ }^{64}$ (I say "their interpretation" because as may be evident in the discussion of the majority judgment above, nothing written by Mogoeng CJ gives this reader such an impression). For Froneman and Cameron JJ, this apparent "constitutional discountenancing" of white cultural history - irrespective of its roots in the genocidal and brutal oppression of African peoples has "momentous implications for a substantial portion of our population". 65 (Statistically, whites make up less than $10 \%$ of the South African population).

Although they also raise a procedural or technical quarrel regarding the issue of leave to appeal against interim interdicts, the more

\footnotetext{
62 Biko 23.

63 Biko 75.

64 City of Tshwane $v$ Afriforum supra, para 81.

65 City of Tshwane $v$ Afriforum supra, para 81.
} 
fundamental question they address themselves to is the question of whether the cultural heritage of white South Africans is inevitably tainted by historical injustice, to which their answer is a strained but resounding "no". For Froneman and Cameron JJ, the white community in South Africa, and specifically Afrikaans-speaking whites, do have a real claim to their culture and this should be recognised by the Constitution. This is a point they believe is being denied by the majority judgment. ${ }^{66}$ They continue to argue that cultural diversity and the legal right to culture are a legitimate part of our "constitutional society" and need to be safeguarded. To this reader, the dissenting judgment is at once defensive and anxious to make a case not only for white South Africans but for a historically neutral approach to race, culture and identity.

For the two judges, the untidiness or complexity of South African history undermines any attempt to legally wipe away the cultural traditions of white South Africa. As illustrations, they cite the controversial legacies of King Shaka Zulu and his role in the Difaqane and Mahatma Ghandi's odious anti-black racist views. ${ }^{67}$ Moreover, the presumed tainting of white culture as wholly rooted in oppression and the implicit assumption in the majority and separate concurring judgments that Afriforum is a "racist" organisation goes against what the judges view as the need for "longer, gentler and more accommodating debate". 68 In other words, according to Froneman and Cameron JJ, the majority judgment is insensitive to the feelings of white South Africans. There is an insistence in their judgment on judicial restraint or jurisprudential discipline, the clear function of which is to prescribe a particular way in which the law should approach racially-contested cases. This suggested way entails racial neutrality, politically-tempered language, a judicial voice discipline by legality, tolerance of radically different views and opinions and in this case, sensitivity to white people's feelings and anxieties. It remains to be asked why the judges construe the issue of street names and cultural identity as an issue of differences in opinion and diverse worldviews when it more pertinently appears to raise questions of power and belonging. Both the question of who belongs to South Africa and to whom does South Africa belong are entangled in the histories of settler-colonialism and racial oppression - a nearly 400-year history characterized by a specifically colour-coded

66 City of Tshwane $v$ Afriforum supra, para 125.

67 Space does not permit an examination of Froneman and Cameron JJ's uncritical reliance on a largely conservative historiography to portray Emperor Shaka of the Zulu kingdom as a despotic and bloodthirsty conqueror. The historical villanisation of Shaka, and the historically contested narrative of the Mfecane period, is generally associated with white settler historical revisionism tied to the downplaying of the effects of European colonial domination. See Kunene Emperor Shaka the Great (2017). There is also no inconsistency between the political repudiation of colonial and apartheid-era cultural histories, monuments and street names and the legitimate critique of Mahatma Ghandi's now well-known anti-black racism, class prejudice, anti-Semitism and attachment to Empire. See Desai and Vahed The South African Ghandi. The Stretch-Bearer of Empire (2015). City of Tshwane v Afriforum supra, para 134; but see also paras 131-134. 
asymmetry of power, dispossession and violence - not merely differences in opinion.

Closer to the end of their judgment, Froneman and Cameron JJ move however to deny the politically and historically contested nature of the issue of street names by claiming that beyond the issue of street names, this case raises "an issue of the rule of law". ${ }^{69}$ In any case, the judges tell us, "the historical past of white people also includes much to not be ashamed of". 70 They do not enumerate what this "much" is and nor do they show which of the old colonial-apartheid street names in Tshwane/ Pretoria or elsewhere for that matter were not placed there as part of the violent process of making South Africa a "white man's country".

\section{Separate concurring judgment}

The schism in the judgment would be continued by Jafta J's reply to the dissenting judges, in which he appears troubled by their suggestion that historically oppressive cultural traditions and symbols which are "racist to the core" do in fact have a place under the Constitution. ${ }^{71}$ In contrast to Froneman and Cameron JJ's call for a "gentle" constitutionalism, Jafta $\mathrm{J}$ articulates an aggressive constitutionalism - one which instantiates a "clean break from our ugly past of racial oppression". ${ }^{72}$ He affirms in stark terms the majority judgment's constitutional repudiation of the "shameful" racial past:

How can that unquestionably transformative Constitution be expected to recognize cultural traditions rooted in the racist past? The answer must be, if there is such expectation, that it is misplaced. The fact that the oppressive racist history exists at the level of fact does not mean that it deserves any recognition in the Constitution. Therefore, the implication which the second judgment says may be drawn from the first judgment, would be the correct one ... It was the shameful racist past properly described in the first judgment which led to streets and buildings in every town in this country, including Pretoria, reflecting exclusively the names of white people. Black people were precluded from residing in these areas, which constituted nearly $90 \%$ of the entire country. They were forced to live in segregated townships designed exclusively for black people and usually far from towns and cities in which they were regarded as providers of labour and nothing more. ${ }^{73}$

For Jafta J, the transformative path prescribed by the Constitution is correctly reflected in the majority judgment. He thus disagrees with the dissenting judgment's construal of the majority decision as a deviation from the rule of law. He concludes on this score that Froneman and Cameron JJ's argument that the Constitution creates scope for the recognition of a legal right or interest based on a sense of belonging tied to a culture rooted in a racist past is untenable: "It does not conform with

69 City of Tshwane $v$ Afriforum supra, para 152.

70 City of Tshwane $v$ Afriforum supra, para 158.

71 City of Tshwane $v$ Afriforum supra, para 163.

72 City of Tshwane $v$ Afriforum supra, para 164.

73 City of Tshwane $v$ Afriforum supra, paras 165, 167 
the clean break from the history characterized by discrimination, humiliation and indignity suffered by black people and which the Constitution loudly rejects." 74

\section{Closing remarks: the "limits" of post- apartheid constitutionalism}

There is no easy way to think and write about the different judgments in this case. The discursive atmosphere they create for the reader is palpably tense, heated and polarized. Of interest in this particular instance is how the level and tone of disagreement and recrimination between the nine Black judges and the two white judges - as well their very different treatments of social history - reflects a deep fracture across post-1994 society. To my mind, this case takes place at the edge, the limit, of the "post"-apartheid constitutional dispensation as it confronts the judges, the Constitution and the country as a whole with the incalculable weight of South Africa's history, the irreparable historical trauma of colonial conquest and the unpayable debt of racial injustice. Although these are not dilemmas specific to historically settler-colonial societies such as South Africa, they do emerge with particular acuteness within them. How, we might ask, can a constitutional text and constitutional jurisprudence enable the ethical reharmonisation of Blacks and whites when their social relations have not yet undergone a process of psychic, economic, spatial and political decolonisation?

It turns out that although the judgments reflect significant differences in the identities and political worldviews of their author-judges at the rhetorical level, they all remain within the same paradigm of constitutional patriotism, liberal multiculturalism, and reconciliation without justice. Despite the sharp contrasts between the vigorous and aggressive constitutionalism of Mogoeng $\mathrm{CJ}$ and Jafta $\mathrm{J}$ and the gentle constitutionalism of Froneman and Cameron JJ, the Constitution as a governing episteme and truth regime is invoked by all the judges in their embrace of diversity, unity and a shared national identity. Because of the institutionalizing function of constitutionalism, which impairs its ability to be reflexive about its own norms and terms, the judges of the Court were not open to the possibility that the explosive racial contradictions at the heart of this case cannot be resolved within the extant constitutional frame precisely because they trouble that frame. It has been voiced before that the political compromises and negotiated settlement that delivered the 1993 and 1996 constitutions elided fundamental questions of justice in favour of unsustainable considerations of stability and peace - and thereby arrested the radical remaking of South African subjectivities and social positions. This is a contention captured by Achille Mbembe's observation that: 
[South Africa] is the only country on Earth in which a revolution took place, which resulted in not one single former oppressor losing anything. In order to keep its privileges intact in the post-1994 era, South African whiteness has sought to intensify its capacity to invest in what we should call the resources of the offshore. It has attempted to fence itself off, to re-maximize its privileges through self-enclaving and the logics of privatization. ${ }^{75}$

In the making of the new constitutional dispensation, at least three pertinent issues were left unaddressed and predictably returned in City of Tshwane to haunt the Court. These are (1) the spatial dimension of colonial-apartheid as tied to the broader exigency of land restoration; (2) the possible dangers of "constitutional supremacy" as a device for limiting and opposing Black majority rule and thereby preventing largescale transformation and redistribution and (3) the specific need for white South Africans to assume individual and collective moral, political and historical responsibility in the building of a truly non-racial society. The foreclosure of these questions could be what explains the impulse expressed in the judgment towards democratising the naming of streets and other public spaces to reflect the "diversity" of South African racial and cultural groups in a way that masks the specificity of South Africa as a black-majority African country under ongoing settler-colonial hegemony. The appeal to a common South African identity, suffused by the Constitution, and marked by an equal sense of belonging for all who live in South Africa, conflates the ideal with the actual by overlooking the fact that white South Africans continue to wield massive social, economic and cultural power despite the constitutional commitment to the values of non-racialism, freedom and equality. ${ }^{76}$ In actuality, therefore, South Africa remains a fundamentally unequal and unreconciled society. ${ }^{77}$

It was precisely because of the persistence of this power and violence of whiteness that one commentator named South Africa "a strange and morally tangled place to live". ${ }^{78}$ This strangeness accounts in some ways for why the struggle to remember and mourn the past in South Africa tends to produce conflict, denial and division. How can a past be mourned when it is ongoing? The repeated references in the judgment to colonial-apartheid in the past tense shows the Court to be blind to the degree of the intransigence of intersubjective and structural racism in South Africa. It is now commonplace in public and academic discourse

75 Mbembe "The State of South African Politics" (9-09-2015) Africa Is a Country http://africasacountry.com/2015/09/achille-mbembe-on-the-stateof-south-african-politics/. The one contention to register against Mbembe's formulation is that precisely because the "former" oppressor lost nothing, it is historically and politically inaccurate to refer to the formal legal transition from apartheid to constitutional democracy in South Africa as a "revolution".

76 See Modiri "The Colour of Law, Power and Knowledge: Introducing Critical Race Theory in (Post-)apartheid South Africa" 2012 SAJHR 405 - 435; Modiri "Law's Poverty" 2015 Potchefstroom Electronic LJ 224-273.

77 See Durrheim et al Race Trouble: Race, Identity and Inequality in Postapartheid South Africa (2011) and Terreblanche Lost in Transformation (2012).

78 Vice "How do I Live in This Strange Place" $2010 \mathrm{~J}$ of Social Philosophy 323. 
to hear talk of the "unfinished business" or incompleteness of the transition to constitutional democracy in South Africa. This underscores an increase in varying levels of recognition that the historic "1994 moment" constituted neither a rupture or radical break with the social and political order of colonial-apartheid nor an introduction of new values, relations and ways of life that could counter those of the old order. If both the material as well as psycho-social conditions that resulted from colonial-apartheid persist into the post-1994 present, it seems then that the stark, even overstated, distinction between the colonial-apartheid "past" and the constitutional-democratic present, as well as the attendant marking of the 1994 multiracial elections and adoption of a new constitution as indexes of freedom, cannot really be assumed or taken for granted. ${ }^{79}$

What the City of Tshwane case ultimately illustrates is that the unresolved history of conquest, which is to say the afterlife of conquest, fractures the very possibility of belonging, reharmonisation and nationbuilding. ${ }^{80}$ This of course implicates the Constitution as well since as the product of a faulty negotiated settlement centered on compromise and the protection of white social, economic and cultural interests rather than justice, the Constitution will always only inadequately contend with these fractures, leaving us with an incomplete and unsustainable experience of (un)freedom. We may conclude then that the challenging insight to be drawn from Ramose's call for historical injustice in South Africa and Christodoulidis' notion of constitutional irresolution is that the irreducible antagonism at the heart of the racial politics in South Africa must be fully reckoned with if there is to be any possibility for the reconstruction of a truly new polity and society, and part of this reckoning will entail a quite critical confrontation with the spirit and letter of the Constitution itself.

[W] hile South Africa may dream a non-racialist future; it resides in a racist present. How to live in a present that assumes the ethics of a not-yet-realized future ${ }^{81}$

79 See e.g Cavanagh "History, Time and the Indigenist Critique" 2012 Arena Journal 16-39.

80 See Qunta Why we are not a nation (2016).

81 Collis-Buthelezi "The Case for Black Studies in South Africa" 2017 The Black Scholar 13. 